\title{
Molecular Detection, Quantification, and Toxigenicity Profiling of Aeromonas spp. in Source- and Drinking-Water
}

\author{
Boakai K. Robertson ${ }^{*}, 1$, Carol Harden ${ }^{1}$, Suresh B. Selvaraju ${ }^{2}$, Suman Pradhan ${ }^{2}$ and \\ Jagjit S. Yadav*,2 \\ ${ }^{I}$ Department of Biological Sciences, Alabama State University, Montgomery, AL 36101. \\ ${ }^{2}$ Department of Environmental Health, University of Cincinnati College of Medicine, Cincinnati OH 45267-0056.
}

\begin{abstract}
Aeromonas is ubiquitous in aquatic environments and has been associated with a number of extragastrointestinal and gastrointestinal illnesses. This warrants monitoring of raw and processed water sources for pathogenic and toxigenic species of this human pathogen. In this study, a total of 17 different water samples $[9$ raw and 8 treated samples including 4 basin water (partial sand filtration) and 4 finished water samples] were screened for Aeromonas using selective culturing and a genus-specific real-time quantitative PCR assay. The selective culturing yielded Aeromonas counts ranging $0-2 \times 10^{3} \mathrm{CFU} / \mathrm{ml}$ and 15 Aeromonas isolates from both raw and treated water samples. The qPCR analysis indicated presence of a considerable nonculturable population $\left(3.4 \times 10^{1}-2.4 \times 10^{4}\right.$ cells $\left./ \mathrm{ml}\right)$ of Aeromonas in drinking water samples. Virulence potential of the Aeromonas isolates was assessed by multiplex/singleplex PCR-based profiling of the hemolysin and enterotoxin genes viz cytotoxic heat-labile enterotoxin (act), heat-labile cytotonic enterotoxin (alt), heat-stable cytotonic enterotoxin (ast), and aerolysin (aerA) genes. The water isolates yielded five distinct toxigenicity profiles, viz. act, alt, act +alt, aerA+alt, and aerA+alt+act. The alt gene showed the highest frequency of occurrence (40\%), followed by the aerA (20\%), act (13\%), and ast (0\%) genes. Taken together, the study demonstrated the occurrence of a considerable population of nonculturable Aeromonads in water and prevalence of toxigenic Aeromonas spp. potentially pathogenic to humans. This emphasizes the importance of routine monitoring of both source and drinking water for this human pathogen and role of the developed molecular approaches in improving the Aeromonas monitoring scheme for water.
\end{abstract}

Keywords: Aeromonas, drinking water, real-time qPCR, singleplex and multiplex PCR, virulence genes.

\section{INTRODUCTION}

Aeromonas is a gram-negative bacterium of the family Vibrionaceae and is widely distributed across clinical, food, and environmental niches. Environmental Aeromonads consitute a high percentage of heterotrophic microbes in a variety of aquatic and terrestrial systems [1]. Aeromonas spp. have been implicated as the etiological agents of extraintestinal and intestinal infections, including, but not limited to community acquired infection, nosocomial infection, traveler's diarrhea and infections associated with natural disasters such as hurricanes, tsunamis, and earthquakes [1,2-4]. Aeromonas spp. are infectious as well as enterotoxigenic infecting people of all age groups. A variety of potential virulence factors and toxins have been characterized [1,5-15] and associated with different illnesses in humans. The various toxins that have been associated with Aeromonas pathogenesis include a cytotoxic heat-labile enterotoxin $(a c t)$, a cytotonic heat-labile enterotoxin (alt), a

*Address correspondence to these authors at the Microbial Pathogenesis Laboratory, Dept. of Environmental Health, University of Cincinnati Medical Center, 3223 Eden Avenue, Cincinnati OH 45267-0056;

Tel: (513)558-4806; Fax: (513) 558-4397; E-mail: Jagjit.Yadav@uc.edu; Department of Biological Sciences, Alabama State University, Montgomery, AL 36101-0271, USA. Tel: +334-229-4423;
Fax: +334-229-1007; E-mail: brobertson@alasu.edu cytotonic heat-stable enterotoxin (ast) and an aerolysin toxin (aerA). These toxins may therefore serve as potential markers for differentiation of pathogenic from nonpathogenic Aeromonas species.

While majority of the studies on pathogenic Aeromonads have been focused on clinical sources, little is known on pathogenic species from environmental sources including water supplies. Understanding the prevalence of pathogenic Aeromonas species in water sources is critical in assessing the risk of water-to-human transmission and imminent infections [16]. Rapid and specific methods for isolation, identification, and enumeration may assist in the timely control and prevention of potentially pathogenic Aeromonads associated with water sources from reaching the human population. The conventional US EPA-recommended culture-based method (number 1605) currently used to monitor Aeromonas load in drinking water is timeconsuming, laborious, and yields only the culturable viable cells of Aeromonas. Culture-independent methods, such as PCR could therefore offer a better measure for the detection, quantification and monitoring in environmental samples [17] and could be a reliable and effective alternative for early detection of Aeromonas population in water samples [18]. Identification of Aeromonas isolates using the DNA-DNA 
hybridization analyses $[19,20]$ and/or PCR assays based on common phylogenetic markers such as 16S rRNA [13] cannot reveal the pathogenic versus nonpathogenic character of the unknown Aeromonas isolates. A promising approach for such differentiation of potentially pathogenic Aeromonas isolates may require the use of virulence gene markers [16, 21-23].

In light of the above background, the current study was focused on the following specific aspects: (i) Reliable was detection and estimation of Aeromonas spp. in water sources (source water and municipal drinking water) using genusspecific PCR approach; (ii) isolation of Aeromonas strains from water samples and their profiling for the presence and distribution of virulence genes critical in conferring pathogenicity.

\section{MATERIALS AND METHODS}

\section{Strains}

Reference strains of eight Aeromonas species viz. A. hydrophila (type strain ATCC 7966), A. jandaei (ATCC 49568), A. caviae (ATCC 15468), A. media (ATCC 35950), A. trota (ATCC 49659H1), A. veronii (ATCC 35624), A. eucrenophila (ATCC 23309) and A. sobria (ATCC 43979) were obtained from American Type Culture Collection (ATCC, Manassas, VA).

\section{Sampling of Source Water and Drinking Water}

Source water and drinking water samples were collected from several previously determined sampling sites on the Alabama River and from the Montgomery municipal water treatment plant. The samples were designated as Raw or Source water samples (collected Upstream and Downstream from the Alabama river) and Treated or Processed water samples from the Municipal water treatment plant, including Finished or Drinking water samples (collected after chlorination), Basin water samples (collected after partial sand filtration), and Raw water storage tank samples. A total of 9 samples were collected from the Alabama River and 8 from the treatment plant. River samples were taken at approximately $200 \mathrm{~mm}$ depth from the surface at each sampling site. All samples were processed within 24 to 48 hours of collection.

\section{Culturing of Aeromonads}

One hundred milliliter of source water sample $(50 \mathrm{ml}$ diluted to $100 \mathrm{ml}$ with sterile water) and $500 \mathrm{ml}$ of treated water were filtered through a sterile cellulose membrane filter of pore size $0.2 \mu \mathrm{m}$, diameter $47 \mathrm{~mm}$ (Millipore, Boston, MA) and the filters were incubated overnight either on the Aeromonas specific medium ADA-V with ampicillin (BD Biosciences, San Jose, CA) or Tryptic Soy Agar (TSA) (Difco Laboratories, Sparks, MD) at $35^{\circ} \mathrm{C}$ in triplicates. Total colonies on either medium were counted under a dissecting microscope and distinctive yellow colonies with diameter of 1-3 mm on ADA-V medium were picked and streaked three successive times on freshly prepared ADA-V medium for isolation and purification of bacteria.

\section{DNA Isolation from Water Samples and Aeromonas}

A $50 \mathrm{ml}$ aliquot of each water sample was centrifuged three times at 10,000 rpm for 10 min using the Sorvall RC 5B plus centrifuge (Sorvall, Asheville each, NC). The cell pellets from water samples were used for DNA extraction by following the Bactozol DNA isolation protocol modified as described in our earlier study [24]. For isolation of DNA from Aeromonas strains and isolates, the organism was grown to 120 Klett reading measured using Klett Photoelectric Colorimeter (Klett, New York, NY). One ml of each culture was centrifuged at $10,000 \mathrm{rpm}$ for $10 \mathrm{~min}$ to obtain the cell pellet for DNA isolation using the same

Table 1. Primer pairs used for the detection of Aeromonas enterotoxin and hemolysin genes.

\begin{tabular}{|c|c|c|c|c|c|c|}
\hline $\begin{array}{l}\text { Primer } \\
\text { Pair }\end{array}$ & Sequence (5'-3') & Target Gene & $\begin{array}{c}\text { Location Within Gene } \\
\text { (5'to 3' Base Pair } \\
\text { Positions) }\end{array}$ & $\begin{array}{c}\text { Size of } \\
\text { Amplicon } \\
\text { (bp) }\end{array}$ & $\begin{array}{l}\text { Accession } \\
\text { Number }\end{array}$ & Reference \\
\hline $\begin{array}{l}\text { A16SF } \\
\text { A16SR }\end{array}$ & $\begin{array}{c}\text { GGGAGTGCCTTCGGGAATCAGA } \\
\text { TCACCGCAACATTCTGATTTG }\end{array}$ & $16 S r R N A$ & $\begin{array}{l}1020-1041 \\
1375-1355\end{array}$ & 356 & X74677 & 22 \\
\hline $\begin{array}{l}\mathrm{AHCF} \\
\mathrm{AHCR}\end{array}$ & $\begin{array}{l}\text { GAGAAGGTGACCACCAAGAACA } \\
\text { AACTGACATCGGCCTTGAACTC }\end{array}$ & $a c t$ & $\begin{array}{l}1661-1682 \\
1892-1871\end{array}$ & 232 & M84709 & 17 \\
\hline $\begin{array}{l}\text { AHLF } \\
\text { AHLR }\end{array}$ & $\begin{array}{l}\text { TGCTGGGCCTGCGTCTGGCGG } \\
\text { AGGAACTCGTTGACGAAGCAGG }\end{array}$ & alt & $\begin{array}{c}686-707 \\
1046-1025\end{array}$ & 361 & L77573 & 21 \\
\hline $\begin{array}{l}\text { gyrB-F } \\
\text { gyrB-R }\end{array}$ & $\begin{array}{l}\text { GAAGGCCAAGTCGGCCGCCAG } \\
\text { ATCTTGGCATCGCCCGGGTTTTC }\end{array}$ & $\operatorname{gyr} B$ & $\begin{array}{c}912-932 \\
1109-1086\end{array}$ & 198 & $\begin{array}{l}\text { F074917 and } \\
\text { AF208250- } \\
\text { AF208260 }\end{array}$ & 13 \\
\hline
\end{tabular}


protocol as for the water samples.

\section{Genus-specific Real-time Quantitative PCR for Quantification of Total Aeromonads}

The real-time qPCR was optimized on SmartCycler II platform (Cepheid, Sunnyvale, CA) using Aeromonas genusspecific primers targeting 198-bp region of gyrB gene (Table 1). The reaction mixture $(20 \mu \mathrm{l})$ contained $10 \mu \mathrm{l}$ of $2 \mathrm{X}$ Brilliant SYBR Green QPCR master mix (Stratagene, La Jalla, CA), $200 \mathrm{nM}$ of each primer, and $50 \mathrm{ng}$ of template DNA. Cycling conditions included initial denaturation for $10 \mathrm{~min}$ at $95^{\circ} \mathrm{C}$, and 45 cycles of amplification, each for $20 \mathrm{~s}$ at $95^{\circ} \mathrm{C}, 30 \mathrm{~s}$ at $56^{\circ} \mathrm{C}$, and $30 \mathrm{~s}$ at $72^{\circ} \mathrm{C}$. Melting curves were generated by measuring the fluorescent signal while raising the temperature as follows: $15 \mathrm{~s}$ at $95^{\circ} \mathrm{C}, 15 \mathrm{~s}$ at $60^{\circ} \mathrm{C}$ and temperature increase from 60 to $95^{\circ} \mathrm{C}$ with a temperature transition rate of $0.1{ }^{\circ} \mathrm{C} \mathrm{s}^{-1}$. The specificity of the primer set was validated against the 8 reference strains of Aeromonas spp. Using the above optimized real-time PCR amplification conditions, a standard curve for quantification of Aeromonas was prepared using increasing amount of DNA corresponding to increasing number of $A$. hydrophila cells $\left(10^{\circ}\right.$ through $10^{6}$ cells $/ \mathrm{ml}$ ); the master stock was prepared by growing the reference strain to a 120 Klett reading and quantifying the cell count by spread plating and incubation (24 h) on ADA-V agar (with ampicillin). The cycle threshold $(\mathrm{Ct})$ values were plotted against the cell count (determined based on culturing). Known aliquots of the isolated DNA from water samples were used for the detection of total Aeromonas per $\mathrm{ml}$ based on the developed standard curve. The quality of amplification reactions was confirmed by analyzing the melting peaks of amplicons and comparing them to standard melting peak obtained for Aeromonas. Additionally the amplification quality was confirmed by electrophoresing $(70 \mathrm{~V}, 1 \mathrm{~h})$ the PCR product $(10 \mu \mathrm{l})$ using $1 \%$ Trevigel gel matrix (Trevigen, Gaithersburg, MD) in $1 \mathrm{x}$ TAE buffer containing ethidium bromide $\left(0.5 \mathrm{ug} / \mathrm{ml}^{-1}\right)$ and 100 bp DNA size marker (Invitrogen Carlsbad, CA).

\section{Virulence Gene Profiling Using Singleplex and Multiplex PCR Protocols}

Two separate protocols of multiplex PCR were optimized based on two sets of target genes, set I (16S rRNA and $g y r \mathrm{~B}$ set with or without aerA) to confirm the identity of individual isolates and set II (act, alt and ast) to understand their virulence potential (a singleplex PCR protocol was used to target the aerolysin gene aerA because of its differing annealing temperature requirement). All primer sets used for these protocols are listed in Table $\mathbf{1}$. The gyrase B gene (gyrB) was targeted for the genus-specific amplification wherein 16S rRNA served as an internal control.

\section{Amplification Conditions}

Multiplex PCR protocol I based on the target gene combination $16 S$ rRNA-gyrB or $16 S$ rRNA-gyrB-aerA and singleplex PCR protocol based on aerA, were performed using a $25 \mu 1$ reaction volume. The reaction mixture consisted of $20 \mathrm{ng}$ template DNA, 1x reaction buffer

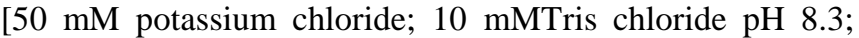
$25 \mathrm{mM}$ magnesium chloride], $200 \mu \mathrm{M}$ each of dNTPs (dATP,
dCTP, dGTP, and dTTP), 20 pmol each of the primers, and 1.2 U Takara Ex Taq ${ }^{\mathrm{TM}}$ DNA polymerase (Takara Bio Inc, Dalian). Amplifications were performed on a GeneAmp 2400 DNA thermal cycler (Applied Biosystems, Foster City, CA). Amplification conditions were as follows: initial denaturation at $95^{\circ} \mathrm{C}$ for $30 \mathrm{~s}, 50$ cycles of amplification [each involving denaturation at $95^{\circ} \mathrm{C}$ for $30 \mathrm{~s}$, annealing at $59^{\circ} \mathrm{C}$ for $30 \mathrm{~s}$, and extension at $72^{\circ} \mathrm{C}$ for $\left.30 \mathrm{~s}\right]$ and a final extension step at $72^{\circ} \mathrm{C}$ for $7 \mathrm{~min}$.

Multiplex PCR protocol II based on the target gene set act-alt-ast was performed under similar reaction conditions (DNA template amount and reaction mixture) as protocol I. However, the amplification parameters included an initial heating step $\left(95^{\circ} \mathrm{C}\right.$ for $\left.15 \mathrm{~min}\right)$ followed by 35 cycles of amplification using GeneAmp 2720 Thermal Cycler system (Applied Bio Systems, Foster city, CA). Each amplification cycle involved the following: denaturation $\left(95^{\circ} \mathrm{C}\right.$ for $\left.15 \mathrm{~s}\right)$, annealing $\left(69^{\circ} \mathrm{C}\right.$ for $\left.30 \mathrm{~s}\right)$, and extension $\left(72^{\circ} \mathrm{C}\right.$ for $\left.30 \mathrm{~s}\right)$. To conclude the amplification process, a final elongation step was performed at $72^{\circ} \mathrm{C}$ for $10 \mathrm{~min}$. The PCR product was resolved by gel electrophoresis using $1.5 \%$ agarose containing ethidium bromide and examined under UV. Identity of the amplicons was confirmed by comparison of the amplicon sizes with the predicted sizes, as shown in Table 3 .

\section{RESULTS}

\section{Culturable Aeromonads in Drinking Water and Source Water}

Of the 17 water samples [ 9 raw samples and 8 processed samples which comprised of 4 basin water (partial sand filtration), and 4 finished water samples], 14 yielded bacterial colonies ranging $2 \times 10^{1}-5.4 \times 10^{6} \mathrm{CFU} / \mathrm{ml}$ when cultured on the general bacterial growth medium Trypticase Soy Agar (Table 2). Likewise, when cultured on the Aeromonas selective medium ADA-V, the samples yielded putative Aeromonas colonies $\left(0-1.98 \times 10^{3} \mathrm{CFU} / \mathrm{ml}\right)$ (Table 2). A total of 15 isolates were derived by successive passaging of the putative colonies on the selective medium ADA-V. Isolates originated not only from the raw water samples but also from treated water samples, and were picked based on the characteristic yellow pigmented colonies on the ADA-V agar plates. The isolates were arbitrarily designated as ADA-V I-1, ADA-V I-2, ADA-V I-3, ADA-V I-4, ADA-V I-5, ADA-V I-6, ADA-V I-7, ADA-V I-9, ADA-V I-10, ADA-V I-11, ADA-V I-12，R'1B，R'4B, R'3A, and DS'1A.

\section{Genus-specific Real-time PCR-based Detection and Quantification of Total (Culturable and Nonculturable) Aeromonads in Water Samples}

For quantitation of total Aeromonads by the genusspecific real-time PCR-based protocol optimized using reference strain of $A$. hydrophila, a standard curve was generated by varying the Aeromonas cell count $\left(10^{0}\right.$ to $\left.10^{6}\right)$. The quantification limit was as low as 10 cells/ml. (Fig. S1), although a minimum of $1 \mathrm{cell} / \mathrm{ml}$ was detectable based on the amplification growth curve. The standard curve showed a correlation coefficient $\left(\mathrm{R}^{2}\right)$ value of 1.0 (Fig. S1 panel A). A 
Table 2. Genus-specific real-time qPCR-based quantification of total Aeromonads (culturable and nonculturable) and selective culturing-based quantification of culturable Aeromonads in water samples.

\begin{tabular}{|c|c|c|c|c|c|c|}
\hline \multirow{2}{*}{$\begin{array}{c}\text { Water Sample } \\
\text { ID }\end{array}$} & \multirow{2}{*}{$\begin{array}{l}\text { Sampling } \\
\text { Source }^{c}\end{array}$} & \multicolumn{2}{|c|}{ Culturable Count (CFU/ml) } & \multicolumn{2}{|c|}{ Total Aeromonads (qPCR-based) } & \multirow{2}{*}{$\begin{array}{c}\begin{array}{c}\text { Nonculturable } \\
\text { Aeromonads }^{\mathrm{d}}\end{array} \\
\text { Counts } / \mathrm{ml}\end{array}$} \\
\hline & & ${ }^{\mathrm{a} A l l}$ Bacteria & ${ }^{\mathrm{b}}$ Aeromonas & Ct Value & Counts/ml & \\
\hline S-01 & DS-1 & $5.4 \times 10^{6}$ & 1980 & 19.21 & $2.6 \times 10^{4}$ & $2.4 \times 10^{4}$ \\
\hline S-02 & DS-1 & $5.0 \times 10^{6}$ & 1965 & 19.88 & $2.4 \times 10^{4}$ & $2.2 \times 10^{4}$ \\
\hline S-04 & DS-2 & $0.2 \times 10^{6}$ & 735 & 22.14 & $8.5 \times 10^{3}$ & $7.8 \times 10^{3}$ \\
\hline S-05 & US-1 & $5.1 \times 10^{5}$ & 630 & 23.28 & $4.6 \times 10^{3}$ & $4.0 \times 10^{3}$ \\
\hline S-06 & US-2 & $4.8 \times 10^{5}$ & 614 & 23.49 & $4.5 \times 10^{3}$ & $3.9 \times 10^{3}$ \\
\hline S-07 & US-2 & $4.4 \times 10^{5}$ & 610 & 23.58 & $4.4 \times 10^{3}$ & $3.8 \times 10^{3}$ \\
\hline S-10 & Bas-1 & $2.3 \times 10^{4}$ & 240 & 27.71 & $1.2 \times 10^{3}$ & $9.6 \times 10^{2}$ \\
\hline S-11 & Bas-1 & $2.2 \times 10^{4}$ & 234 & 27.99 & $3.3 \times 10^{3}$ & $3.1 \times 10^{3}$ \\
\hline S-12 & Bas-2 & $1.8 \times 10^{4}$ & 150 & 28.96 & $9.8 \times 10^{2}$ & $8.3 \times 10^{2}$ \\
\hline S-13 & Fin-1 & 0 & 0 & 30.68 & $3.0 \times 10^{2}$ & $3.0 \times 10^{2}$ \\
\hline S-14 & Fin-2 & 0 & 0 & 33.83 & $3.4 \times 10^{1}$ & $3.4 \times 10^{1}$ \\
\hline S-15 & Fin-1 & 20 & 0 & 30.78 & $2.9 \times 10^{2}$ & $2.9 \times 10^{2}$ \\
\hline S-16 & Fin-2 & 0 & 0 & 33.22 & $3.5 \times 10^{1}$ & $3.5 \times 10^{1}$ \\
\hline S-17 & Bas-2 & $2.0 \times 10^{4}$ & 201 & 28.04 & $3.3 \times 10^{3}$ & $3.1 \times 10^{3}$ \\
\hline
\end{tabular}

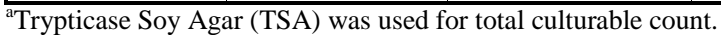

${ }^{\mathrm{b}} \mathrm{ADA}-\mathrm{V}$ agar supplemented with ampicillin and vancomycin enrichment was used for culturable Aeromonas count.

'Sampling details: DS - Down Stream, US - Up Stream, RWST - Raw Water Storage Tank, Bas- Basin water; Fin - Finished Water. Designation "1" refers to water samples collected in late spring whereas " 2 " refers to samples collected in mid-summer.

${ }^{\mathrm{d}}$ Nonculturable Aeromonad counts were calculated by subtracting the culturable Aeromonad count from the total (qPCR-based) Aeromonad count.

typical growth curve consistent with the expected amplicon was detected (Fig. S1 panel B). Dissociation curve analysis (Fig. S1 panels $\mathrm{C}$ and $\mathrm{D}$ ) showed that the melting temperature of the Aeromonas amplicon was $84^{\circ} \mathrm{C}$ while the negative control (without DNA template) did not show such melting peak and instead showed a nonspecific background product with a minor melting peak at $81{ }^{\circ} \mathrm{C}$. Agarose gel electrophoresis of the amplicon (198 bp) showed absence of any primer dimers confirming the desired quality of amplification. The genus-specific nature of the assay was validated using the established reference species of this genus namely $A$. media, A. jandaei, $A$. caviae, A. eucrenophila, A. hydrophila, A. trota, A. sobria, and A. veronii.

The developed genus-specific protocol enabled detection and quantification of total (culturable and nonculturable) Aeromonas in the DNA preparations isolated from the water samples. Of the 17 samples, only 8 samples yielded Aeromonas colonies on selected media whereas 10 samples yielded the PCR amplification signals (Table 2). The deduced count in the culture-negative samples ranged 3.4 x $10^{1}-3 \times 10^{2}$ cells $/ \mathrm{ml}$. All the PCR positive samples showed amplicon melting peaks comparable to those for the standard $\left(84^{\circ} \mathrm{C}\right)$. Agarose gel electrophoresis confirmed the quality of amplification of the expected size amplicons for the water samples (data not shown).

\section{Multiplex- and Singleplex- PCR- based Profiling of Toxin Genes in Reference Strains and Water Isolates}

The reference strains harbored at least one of the four targeted toxin genes viz. aerA, alt, ast, and act (Table 3). The distribution was as follows: ast gene only in A. hydrophila strain, act gene only in A.veronii, aerA gene only in A. hydophila and A. eucrenophila, and alt gene in all strains except for $A$. veronii. Only one of the three enterotoxin genes (act, alt, ast) occurred in the individual reference strains, except for $A$. hydrophila strain that harbored both the heat-labile and heat-stable enterotoxin genes alt and ast (Fig. S2). Some of the isolates did not yield the expected amplicons for the virulence genes as well as the genus-specific gyrB gene amplicon (Figs. S4 and S8) implying that not all isolates belonged to the Aeromonad group (Fig. S5). Furthermore, the isolates showed a variable distribution of the virulence gene(s). Specifically, cytotoxic 
enterotoxin gene act was seen in the isolates ADA-V I-1 and DS'1A (Fig. S3), heat-labile enterotoxin gene alt was present in isolates ADA-V I-2, ADA-V I-4, R'1B, R'4B, R'3A and DS'1A (Fig. S3) whereas the ast gene was not detected from any of the isolates. The aerolysin gene aerA was detected in 3 of the isolates namely R'4B, R'3A and DS'1A (Fig. S6) thereby showing a $20 \%$ frequency of occurrence. Cooccurrence of the genes encoding enterotoxin (act, alt and/or ast) and aerolysin (aerA) is a characteristic of $A$. hydrophila. A similar observation for R'4B, R'3, and DS'1A (Figs. S6 and S7) therefore implies that these three isolates may belong to the A. hydrophila species. We observed that the aerA gene always occurred in combination with the enterotoxin gene alt of the heat-labile family. Cytotoxic enterotoxin gene act that was seen only in the $A$. veronii reference strain was detected in the isolates ADA-V I-1 and DS' 1A (Fig. S7). A multi-gene profile consisting of aerolysin and two enterotoxins (aerA/act/alt) was observed only for the isolate DS'1A (Table 3).

\section{DISCUSSION}

\section{Culturable and Nonculturable Aeromonads in Water Sources}

Recovery of Aeromonads from water in conventional culture-based monitoring may be masked because of several possible reasons. These may include loss of culturability as a result of prevailing nutrient-limited or harsh conditions and inappropriate storage, presence of competing or fast-growing

Table 3. Toxin gene profiles in Aeromonas reference strains and isolates.

\begin{tabular}{|c|c|c|c|c|c|c|}
\hline \multirow[b]{2}{*}{$\begin{array}{c}\text { Aeromonas- Reference } \\
\text { Species or Isolate } \\
\text { Name }\end{array}$} & \multicolumn{6}{|c|}{ Target Gene (With Amplicon Size) } \\
\hline & $\begin{array}{c}16 S \text { rRNA } \\
(356 \mathrm{bp})\end{array}$ & $\begin{array}{c}\text { gyrB } \\
(198 \text { bp) }\end{array}$ & $\begin{array}{c}\text { aerA } \\
\text { (Aerolysin) } \\
(309 \text { bp) }\end{array}$ & $\begin{array}{c}A c t \\
\text { (cytotoxic Heat-labile } \\
\text { Enterotoxin) } \\
(232 \text { bp) }\end{array}$ & $\begin{array}{c}\text { Alt } \\
\text { (Heat-labile } \\
\text { Cytotonic } \\
\text { Enterotoxin } \\
\text { (361 bp) }\end{array}$ & $\begin{array}{c}\text { Ast } \\
\text { (Heat-stable } \\
\text { Cytotonic } \\
\text { Enterotoxin) } \\
\text { (536 bp) }\end{array}$ \\
\hline A. caviae & + & + & - & - & + & - \\
\hline A. veronii & + & + & - & + & - & - \\
\hline A. media & + & + & - & - & + & - \\
\hline A. jandaei & + & + & - & - & + & - \\
\hline A. sobria & + & + & - & - & + & - \\
\hline A. hydrophila & + & + & + & - & + & + \\
\hline A. eucrenophila & + & + & + & - & + & - \\
\hline A. trota & + & + & - & - & + & - \\
\hline ADA-V I-1 & + & + & - & + & - & - \\
\hline ADA-V I-2 & - & - & - & - & + & - \\
\hline ADA-V I-3 & - & - & - & - & - & - \\
\hline ADA-V I-4 & - & + & - & - & + & - \\
\hline ADA-V I-5 & + & - & - & - & - & - \\
\hline ADA-V I-6 & - & - & - & - & - & - \\
\hline ADA-V I-7 & - & - & - & - & - & - \\
\hline ADA-V I-9 & - & - & - & - & - & - \\
\hline ADA-V I-10 & - & + & - & - & - & - \\
\hline ADA-V I-11 & - & + & - & - & - & - \\
\hline ADA-V I-12 & + & - & - & - & - & - \\
\hline R'1B & + & + & - & - & + & - \\
\hline$R^{\prime} 4 B$ & + & + & + & - & + & - \\
\hline$R^{\prime} 3 A$ & + & + & + & - & + & - \\
\hline DS' $1 \mathrm{~A}$ & + & + & + & + & + & - \\
\hline
\end{tabular}


background microflora, and lack of appropriate growth media that enable revival of the nonculturable cells and detection of a low number of viable cells [25]. The genusspecific real-time PCR-based protocol optimized for water samples in this study circumvented these limitations and allowed for direct detection and quantification of total Aeromonads, including even the nonculturable (viable/nonviable) cells as observed in case of finished water samples. For these drinking water samples, while selective culturing method did not yield any Aeromonas colonies, the genusspecific real-time PCR yielded Aeromonas counts $\left(3.4 \times 10^{1}\right.$ to $3.0 \times 10^{2}$ cells $\left./ \mathrm{ml}\right)$. This difference in the outcome by the two methods (culturing and PCR) implied the presence of considerable population of nonculturable cells (viable-butnonculturable and non-viable cells) of Aeromonas in these samples.

The optimized Aeromonas-specific PCR assay based on the universally distributed bacterial genome target DNA gyrase subunit B ( gyrB) gene is a promising alternative to the $16 \mathrm{~S}$ rRNA-based PCR protocols [13, 26]. This assay offers numerous advantages over the 16S rRNA-RFLP assay [27] considering that it is rapid and has the ability to analyze in real time, the two desirable features for high throughput applications. The results demonstrated that the assay as applied to water samples is fairly rapid as it took an estimated 3-4 hours time including the DNA extraction step (70-90 $\mathrm{min}$ ) and the real-time PCR protocol (90 min-2 hours) as compared to the conventional culturing-based approach which may take an estimated 1-2 days. This feature is particularly useful for timely monitoring of the pathogenic Aeromonas species which may escape chlorination in municipal water systems. The protocol utilized a 384 well microtiter plate format, which allows for testing of a large number of samples in a given run thereby offering a high throughput analysis. Also, the optimized protocol utilized fluorescent dye SYBR Green as against the cost-intensive fluorogenic probes. Another significant aspect of this protocol is the integration of our optimized method for direct DNA recovery and purification from field samples of source water and drinking water without culturing or enrichment. Source water may contain diverse co-occurring contaminants including organic and inorganic debris and metal particles which may act as inhibiting factors in microbial/DNA recovery and PCR reaction [28]. The DNA extraction procedure yielded DNA with quality and quantity suitable for downstream qPCR application on water DNA preparations. The assay showed a desirable minimum quantification limit $(10$ cells $/ \mathrm{ml})$, and the minimum detection limit $(1 \mathrm{cell} / \mathrm{ml})$.

\section{Pathogenicity Potential of the Aeromonas spp. Isolated from Water Sources}

In the event of poisoning or diarrheal outbreaks from food and environmental sources, recovery of an Aeromonas strain expressing hemolysins/enterotoxins may imply a hazard [1,4]. Conventionally, assessment of Aeromonas pathogenicity potential requires an evaluation of individual virulence phenotypes including production of individual hemolysins/enterotoxins. The phenotypic methods however may not always detect the presence of the toxins. For instance, animal passage of $A$. caviae isolates that did not produce detectable cytotoxic or hemolytic activity in the phenotypic assays helped regain the toxin-expressing ability; however, they lost it again upon subsequent subculturing [29]. Likewise, other studies have demonstrated the role of specific culture conditions in production of cytotoxin by Aeromonas strains [30]. In this context, molecular screening approach for specific toxigenicity factors may offer the potentially effective way of assessing the virulence potential of Aeromonas isolates. From the repertoire of virulence factors in Aeromonas, the major toxins aerolysins and enterotoxins have been linked with its pathogenicity [31]. Molecular assays targeting the virulence factor genes have been extensively investigated in the last decade [17, 32-35]. While majority of these assays are based on one specific virulence gene, multiplexing using multiple targets has been reported. The multiplex PCR protocols employed in the current study incorporated the key virulence genes alt, act and/or ast which encode the heat-labile (non-cholera toxin cross-reacting Shiga-like toxins) and heat-stable (crossreacting and non-cross-reacting cholera toxin) enterotoxins [7, 19].

\section{Distribution of Toxin Genes}

The tested virulence genes did not appear to be distributed universally among the different Aeromonas species except for $A$. hydrophila that was positive both for the aerolysin (aerA) as well enterotoxin genes (namely the heat labile (alt) and heat-stable (ast) cytotonic enterotoxin genes). Of the Aeromonas cultures investigated, only two of the eight reference strains, and three of the 15 water isolates carried the aerolysin gene which always co-occurred with one or more enterotoxin genes. Taken together, the water isolates yielded five distinct toxigenicity profiles, viz. act, alt, act+alt, aerA/alt, and aerA+alt+act. The most prevalent toxin gene detected by the multiplex PCR in the water isolates was alt (40\%) when compared to the frequency of occurrence of the cytotoxin genes act $(13.3 \%)$ and ast $(0 \%)$ and the aerolysin gene aerA (20\%) (Table 3).

\section{Act Gene}

Among the Aeromonas species, A. veronii is considered more virulent because of its greater invasiveness and lower LD50 dose [7]. Hence, the presence of act gene in this species and in the two water isolates ADA-VI-1 and DS'1A may imply their relatively higher virulence. Absence of act gene in A. caviae is consistent with the previous reports $[23,36]$ which found it less cytotoxigenic and virulent as compared to the other groups. Though act is an important virulence factor, the absence of this gene marker in some of the Aeromonas isolates in this study does not imply their "not-virulent" nature. In this context, it is noteworthy that the 232-bp act amplicon was not observed for the reference strains of known pathogenic species A. jandaei, A.caviae, A. media, A. sorbia, A. eucrenophila, and A. trota. However, drawing a generalized conclusion on the distribution of hemolytic or enterotoxin genes across the subject Aeromonas species may not be appropriate considering that only a limited number of strains (one per species) were included. 


\section{Ast Gene}

Although the ast gene has been reported in clinical and environmental isolates (ecotypes) of Aeromonas spp. [37, 38], there is limited information on the presence of this gene in water isolates. Consistent with our results on the absence of ast gene in water isolates, previous studies have reported the low occurrence of ast and act genes in Aeromonas isolates and ascribed the absence to the method used and/or geographic difference in virulence gene carriage [29].

\section{CONCLUSION}

Taken together, this study revealed the presence of a considerable nonculturable population of Aeromonads in drinking water based on a genus-specific real-time qPCR assay. On the other hand, the study revealed pathogenicity potential of Aeromonas strains prevalent in various water sources as determined using optimized multiplex/singleplex PCR protocols based on toxin gene markers. Relative distribution of Aeromonas virulence genes followed the order alt $(40 \%)>$ aerA $(20 \%)>$ act $(13 \%)$ in the tested water samples. Detection of toxigenic Aeromonas spp. potentially pathogenic to humans in both source and drinking water samples in this study emphasizes the importance of routine molecular monitoring of various stages of water treatment process (source water through finished/tap water) involved in the generation of drinking water. This may serve as a critical factor in intervention for reducing and eliminating the risk of water-borne Aeromonads in community health.

\section{CONFLICT OF INTEREST}

This is to confirm that the authors have no conflicts of interest with the content of this article.

\section{ACKNOWLEDGEMENTS}

This study was supported in part by the National Institute of Health's RIMI grant P20 MD 000547 (BKR) and University of Cincinnati funds (JSY). Carol Harden acknowledges the financial support by the MARC-USTAR fellowship program of the National Institute of Health grant T34 GM 008176.

\section{REFERENCES}

[1] Janda JM, Abbott SL. The genus Aeromonas: taxonomy, pathogenicity, and infection. Clin Microbiol Rev 2010; 23(1): 3573.

[2] Aggar WA, McCormick JD, Gurwith MJ. Clinical and microbiological features of Aeromonas hydrophila-associated diarrhea. J Clin Microbiol 1985; 21: 909-13.

[3] Wu CJ, Wu JJ, Yan JJ, et al. Clinical significance and distribution of putative virulence markers of 116 consecutive clinical Aeromonas isolates in southern Taiwan. J Infect 2007; 54: 151-8.

[4] Parker JL, Shaw JG. Aeromonas spp. clinical microbiology and disease. J Infect 2011; 62:109-18.

[5] Chakraborty T, Huhle B, Bergbauer H, Goebel W. Cloning, expression, and mapping of the Aeromonas hydrophila aerolysin gene determinant in Escherichia coli. J Bacteriol 1986; 167: 368-74.

[6] Chopra AK, Houston CW, Peterson JW, Jin GF. Cloning, expression, and sequence analysis of a cytolytic enterotoxin gene from Aeromonas hydrophila. Can J Microbiol 1993; 39: 513-23.
[21] Bin Kingombe CI, D'Aoust JY, Huys G, Hofmann L, Rao M, Kwan J. Multiplex PCR method for detection of three Aeromonas enterotoxin genes. Appl Environ Microbiol 2010; 425-33.

[22] Wang G, Clark CG, Liu C, et al. Detection and characterization of the hemolysin genes in Aeromonas hydrophila and Aeromonas sobria by multiplex PCR. J Clin Microbiol 2003; 41(3): 1048-54.

[23] Wang G, Tyler KD, Munro CK, Johnson WM. Characterization of cytotoxic, hemolytic Aeromonas caviae clinical isolates and their identification by determining presence of a unique hemolysin gene. J Clin Microbiol 1996; 34: 3203-5.

[24] Khan IUH, Yadav JS. Real-time PCR assays for genus-specific detection and quantification of culturable and nonculturable mycobacteria and pseudomonads in metalworking fluids. Mol Cell Probes 2004; 18: 67-73.

[25] Figueras MJ, Soler L, Chacon MR, Guarro J, Martinez-Murcia AJ. Extended method for the discrimination of Aeromonas spp. by 16SrRNA RFLP analysis. Int J Syst Evol Microbiol 2000; 50: 2069-73.

[26] Yadav JS, Khan IUH, Fakhari F, Soellner MB. DNA-based methodologies for rapid detection, quantification, and species- or strain-level identification of respiratory pathogens (mycobacteria and pseudomonads) in metalworking fluids. Appl Occup Environ Hyg 2003; 18: 966-75.

[27] Gobat PF, Jemmi T. Comparison of seven selective media for the isolation of mesophilic Aeromonas species in fish and meat. Int $\mathbf{J}$ Food Microbiol 1994; 24: 375-84.

[28] Yamamoto S, Harayama S. PCR amplification and direct sequencing of $g y r B$ genes with universal primers and their application to the detection and taxonomic analysis of 
Pseudomonas putida strains. Appl Environ Microbiol 1995; 61: 1104-9.

[29] Singh, DV, Sanyal SC. Production of hemolysis and its correlation with enterotoxicity in Aeromonas spp. J Med Microbiol 1992; 37: 262-7.

[30] Namdari H, Bottone EJ. Microbiological and clinical evidence supporting the role of Aeromonas caviae as a pediatric enteric pathogen. J Clin Microbiol 1990; 28: 837-40.

[31] Burke V, Robinson J, Beaman J, et al. Correlation of endotoxicity with biotype in Aeromonas spp. J Clin Microbiol 1983; 18: 1196200.

[32] Baloda SB, Krovacek K, Eriksson L, Linne T, Mansson I. Detection of aerolysin gene in Aeromonas strain isolates from drinking water, fish, and foods by polymerase chain reaction. Comp Immunol Microbiol Infect Dis 1995; 18: 17-26.

[33] Kaznowski, A. Identification of Aeromonas strains of different origin to the genomic species level. J Appl Microbiol 1998; 84: 423-30.
[34] Lior H, Johnson WM. Application of polymerase chain reaction (PCR) to detection of the aerolysin gene in whole cell cultures of B-hemolysin Aeromonas hydrophila. Experientia 1991; 47: 421-4.

[35] Pollard DR, Johnson WM, Lior H, Tyler SD, Rozee KR. Detection of the aerolysin gene in Aeromonas hydrophila by the polymerase chain reaction. J Clin Microbiol 1999; 28: 2477-81.

[36] Watson IM, Robinson JO, Burke V, Gracey M. Invasiveness of Aeromonas spp. in relation to biotype virulence factors and clinical features. J Clin Microbiol 1985; 22: 48-51.

[37] Aguilera-Arreola MJ, Hernandez-Rodríguez C, Zuniga G, Figueras MJ, Castro-Escarpulli G. Aeromonas hydrophila clinical and environmental ecotypes as revealed by genetic diversity and virulence genes. FEMS Microbiol Lett 2005; 242: 231-40.

[38] Albert MJ, Ansaruzzaman M, Talukder KA, et al. Prevalence of enterotoxin genes in Aeromonas spp. isolated from children with diarrhea, healthy controls, and the environment. J Clin Microbiol 2000; 38: 3785-90.

Received: November 09, 2013

Revised: January 17, 2014

Accepted: February 9, 2014

(c) Robertson et al.; Licensee Bentham Open.

This is an open access article licensed under the terms of the Creative Commons Attribution Non-Commercial License (http://creativecommons.org/licenses/by-nc/3.0/) which permits unrestricted, non-commercial use, distribution and reproduction in any medium, provided the work is properly cited. 